ポジションペーパー

\title{
下顎大臼歯欠損に対しインプラント支持固定性補綴装置による 治療介入時に付与すべき咬合様式
}

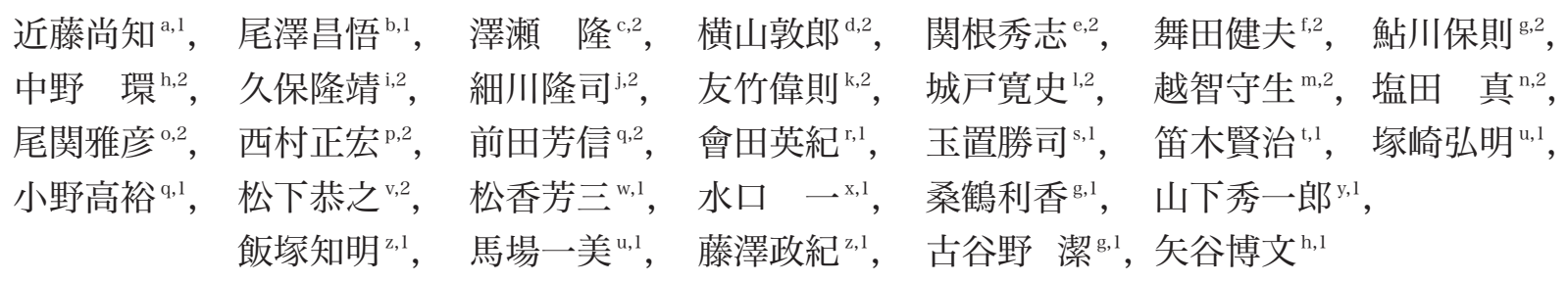

"Occlusal consideration for fixed implant prosthesis in mandibular posterior region"

Hisatomo Kondo, DDS, PhD ${ }^{\mathrm{a}, 1}$, Shogo Ozawa, DDS, $\mathrm{PhD}^{\mathrm{b}, 1}$, Takashi Sawase, DDS, $\mathrm{PhD}^{\mathrm{c}, 2}$, Atsuro Yokoyama, DDS, $\mathrm{PhD}^{\mathrm{d}, 2}$, Hideshi Sekine, DDS, PhD ${ }^{\mathrm{e}, 2}$, Takeo Maida, DDS, PhD ${ }^{\mathrm{f}, 2}$, Yasunori Ayukawa, DDS, PhD ${ }^{\mathrm{g}, 2}$, Tamaki Nakano, DDS, PhD ${ }^{\mathrm{h}, 2}$, Takayasu Kubo, DDS, $\mathrm{PhD}^{\mathrm{i}, 2}$, Ryuji Hosokawa, DDS, $\mathrm{PhD}^{\mathrm{i}, 2}$, Yoritoki Tomotake, DDS, $\mathrm{PhD}^{\mathrm{k}, 2}$, Hirofumi Kido, DDS, $\mathrm{PhD}^{1,2}$, Morio Ochi, DDS, $\mathrm{PhD}^{\mathrm{m}, 2}$, Makoto Shiota, DDS, PhD ${ }^{\mathrm{n}, 2}$, Masahiko Ozeki, DDS, $\mathrm{PhD}^{\mathrm{o}, 2}$, Masahiro Nishimura, DDS, $\mathrm{PhD}^{\mathrm{p}, 2}$, Yoshinobu Maeda, DDS, PhD ${ }^{\mathrm{q}, 2}$, Hideki Aita, DDS, $\mathrm{PhD}^{\mathrm{r}, 1}$, Katsushi Tamaki, DDS, PhD ${ }^{\mathrm{s}, 1}$, Kenji Fueki, DDS, PhD ${ }^{\mathrm{t}, 1}$, Hiroaki Tsukasaki, DDS, $\mathrm{PhD}^{\mathrm{u}, 1}$, Takahiro Ono, DDS, PhD ${ }^{q, 1}$, Yasuyuki Matsushita, DDS, PhD ${ }^{\mathrm{v}, 2}$, Yoshizo Matsuka, DDS, $\mathrm{PhD}^{\mathrm{w}, 1}$, Hajime Minakuchi, DDS, $\mathrm{PhD}^{\mathrm{x}, 1}$, Rika Kuwatsuru, DDS, PhD ${ }^{\mathrm{g}, 1}$, Shuichiro Yamashita, DDS, $\mathrm{PhD}^{\mathrm{y}, 1}$,

Tomoaki, Iizuka, DDS, $\mathrm{PhD}^{z, 1}$, Kazuyoshi Baba, DDS, $\mathrm{PhD}^{\mathrm{u}, 1}$, Masanori Fujisawa, DDS, $\mathrm{PhD}^{\mathrm{z}, 1}$, Kiyoshi Koyano, DDS, $\mathrm{PhD}^{\mathrm{g}, 1}$ and Hirofumi Yatani, DDS, $\mathrm{PhD}^{\mathrm{h}, 1}$

\section{抄 録}

インプラント治療が補綴歯科臨床の場で必要不可欠となった今日においても, 未だ「インプラント支持固定性 補綴装置に付与すべき咬合様式」のガイドラインまたは明確な基準は示されていない. 本ポジションペーパーに おいては，その推奨されるべき一定の基準を示し，臨床上の指針として提案することを目的とした，本稿では， 典型的な欠損形態である下顎大臼歯部欠損にインプラント支持補綴装置を装着した場合を想定している. 口腔 インプラントを適用した治療に関して経験豊富なエキスパートパネルを, (公社) 日本補綴歯科学会会員から選 出し, 臨床の現場における事象を検証した結果として得られた意見を集積し, パネル会議で検討した。その結 果, 補経装置の形態, 咬合接触点の位置と数, 側方運動時の咬合接触の有無, 歯根膜の変位量の考慮, 補綴装 置咬合面の材料等に関する知見が得られ, 推奨される一定の基準が示された。しかしながら, 上記内容は明確 な根拠に支持されるものではなく, 治療効果と術後経過に関する研究が不十分であり, 今後さらなる知見の集 積と検証のもとに，ガイドラインを策定すべきである.

キーワード

インプラント, 固定性補綴装置, 咬合様式, 歯冠形態, 歯根膜

\footnotetext{
a岩手医科大学歯学部補綴・インプラント学講座

${ }^{b}$ 愛知学院大学歯学部有床義歯学講座

c 長崎大学大学院医歯薬学総合研究科口腔インプラント学分野

$d$ 北海道大学大学院歯学研究科口腔機能学講座口腔機能補綴学教室

e 奥羽大学歯学部歯科補経学講座口腔インプラント学

f 北海道医療大学歯学部口腔機能修復・再建学系高度先進補綴学分野

$g$ 九州大学大学院歯学研究院口腔機能修復学講座インプラント・義歯補綴学分野
} 
$\mathrm{h}$ 大阪大学大学院歯学研究科顎口腔機能再建学講座クラウンブリッジ補経学分野

i 広島大学病院口腔維持修復歯科口腔インプラント診療科

$\mathrm{j}$ 九州歯科大学口腔再建リハビリテーション学分野

k 徳島大学病院口腔インプラントセンター

1 福岡歯科大学咬合修復学講座口腔インプラント学分野

${ }^{\mathrm{m}}$ 北海道医療大学歯学部口腔機能修復・再建学系クラウンブリッジ・インプラント補綴学分野

$\mathrm{n}$ 東京医科歯科大学大学院医歯学総合研究科インプラント・日腔再生医学分野

${ }^{\circ}$ 昭和大学歯学部インプラント歯科学講座

${ }^{\mathrm{p}}$ 鹿児島大学大学院医歯学総合研究科顎顔面機能再建学講座口腔顎顔面補綴学分野

$q$ 新潟大学大学院医歯学研究科包括歯科補綴学分野

$r$ 北海道医療大学歯学部口腔機能修復・再建学系咬合再建補綴学分野

$s$ 神奈川歯科大学顎咬合機能回復補綴医学講座

$\mathrm{t}$ 東京医科歯科大学大学院医歯学総合研究科部分床義歯補綴学分野

u昭和大学歯学部歯科補綴学講座

$\mathrm{v}$ 九州大学大学院歯学研究院口腔機能修復学講座口腔生体機能工学研究分野

w 徳島大学大学院医歯薬学研究部顎機能咬合再建学分野

x 岡山大学大学院医歯薬学総合研究科インプラント再生補綴学分野

y 東京歯科大学パーシャルデンチャー補綴学講座

${ }^{z}$ 明海大学歯学部機能保存回復学講座歯科補綴学分野

1 ガイドライン委員会委員

2 ガイドライン委員会エキスパートパネル

a Prosthodontics and Oral Implantology, School of Dentistry, Iwate Medical University

${ }^{\mathrm{b}}$ Department of Removable Prosthodontics, School of Dentistry, Aichi Gakuin University

c Department of Applied Prosthodontics, Graduate School of Biomedical Sciences, Nagasaki University

${ }^{d}$ Department of Oral Functional Prosthodontics, Division of Oral Functional Science, Graduate School of Dental Medicine, Hokkaido University

e Division of Oral Implantology, Department of Prosthodontics, School of Dentistry, Ohu University.

${ }^{\mathrm{f}}$ Division of Advanced Prosthodontics, Department of Oral Rehabilitation, School of Dentistry, Health Sciences University of Hokkaido

'Section of Implant and Rehabilitative Dentistry, Division of Oral Rehabilitation, Faculty of Dental Science, Kyushu University

${ }^{\text {h }}$ Department of Fixed Prosthodontics, Osaka University Graduate School of Dentistry

${ }^{i}$ Clinic of oral implants, Department of preventive and restorative dentistry, Hiroshima University Hospital

${ }^{j}$ Division of Oral Reconstruction and Rehabilitation, Faculty of Dentistry, Kyushu Dental University

${ }^{k}$ Oral Implant Center, Tokushima University Hospital

${ }^{\prime}$ Section of Oral Implantology, Department of Oral Rehabilitation, Fukuoka Dental College

${ }^{\mathrm{m}}$ Division of Fixed Prosthodontics and Oral Implantology, Department of Oral Rehabilitation, School of Dentistry, Health Sciences University of Hokkaido

${ }^{n}$ Oral Implantology and Regenerative Dental Medicine, Graduate School of Tokyo Medical and Dental University

- Department of Oral Implantology, Showa University School of Dentistry

${ }^{\mathrm{p}}$ Department of Oral and Maxillofacial Prosthodontics, Graduate School of Medical and Dental Sciences, Kagoshima University

${ }^{q}$ Division of Comprehensive Prosthodontics, Niigata University Graduate School of Medical and Dental Sciences

${ }^{\mathrm{r}}$ Division of Occlusion \& Removable Prosthodontics, Health Sciences University of Hokkaido

s Department of Prosthodontic Dentistry for Function of TMJ and Occlusion, Kanagawa Dental University

' Removable Partial Prosthodontics, Oral Health Sciences, Graduate School of Medical and Dental Sciences, Tokyo

Medical and Dental University

"Department of Prosthodontics, Showa University School of Dentistry

v Section of Implant and Rehabilitative Dentistry, Division of Oral Rehabilitation, Faculty of Dental Science, Kyushu University

${ }^{w}$ Department of Stomatognathic Function and Occlusal Reconstruction, Institute of Biomedical Sciences, Tokushima University Graduate School

× Department of Oral Rehabilitation and Regenerative Medicine, Okayama University Graduate School of Medicine, Dentistry and Pharmaceutical Sciences

y Department of Removable Partial Prosthodontics, Tokyo Dental College

${ }^{z}$ Division of Fixed Prosthodontics, Meikai University School of Dentistry

${ }^{1}$ Japan Prosthodontic Society, Clinical Guideline Committee

${ }^{2}$ Japan Prosthodontic Society, Implant Expert panel 


\section{I 。緒言}

現在の日本において, 口腔インプラント（以下イン プラント）が年間に出荷される本数は約 60 万本であ り，また約 $20 \%$ の歯科診療所で治療が行われている ことからも，歯科インプラント治療は，欠損補綴に対 する治療方法として必要不可欠なものとなりつつあ る。しかしながら，インプラント治療におけるガイド ラインは未だ十分には確立されておらず，各治療ス テップにおいてもっとも適切な方法が示されていると は言い難い。特に，インプラント支持の固定性補綴装 置に付与する咬合については，ある一定の基準は示さ れているが，エビデンスに基づく明確なものはなく， ほとんどの歯科医師が手探りで上部構造体に咬合を付 与し，咬合調整を行っているのが現状である.

現在までに“1 歯分程度のカンチレバーは, 近心へ の延長でも遠心への延長でも問題を生じない.”など, インプラントの連結やインプラント体と補綴装置との 関係については数多く報告されている ${ }^{1,2)}$. また，ア バットメント・スクリューの緩みと咬合負荷の方向と の関係，インプラント体の非軸方向に加わる咬合力の 影響などについても報告されている象。．しかしなが ら，補綴装置そのものの設計に関する報告，とりわけ 付与すべき咬合様式については, 統一見解が示されて いないのが現状である.

特に, 現在最もよく議論されているのは, 補綴装 置の設計と咬合調整についてである。インプラント 自体には歯根膜組織がないため, 天然歯のような歯 根膜による応力緩衝能力はない. 天然歯の動摇が 25-100 $\mu \mathrm{m}$ であるのに対して，インプラントの動摇 は 3-5 $\mu \mathrm{m}$ であることを考慮すれば，インプラントと 天然歯が混在する歯列において，ライトタッピングで 均等接触するように咬合調整を行った場合, 強く噛み しめた場合にインプラント体と周囲組織，あるいは対 合歯に大きな荷重がかかることは明らかである。この 問題については，現在までに多くの議論がなされてい $ろ^{5-8)}$ 。しかしながら，その荷重（ストレス）が，イ ンプラント体あるいは補経装置, 歯槽骨等のインプラ ント周囲組織にどのような影響を及ぼすかを臨床的に 明らかにしている報告はない ${ }^{9-11)}$.

したがって，日常臨床においても，インプラント支 持固定性補綴装置による治療介入時，どのような咬合 を付与すべきなのか疑問に思うことも多い. そこで, エビデンスに基づいた統一見解の得られていないイン プラント支持固定性補綴装置に付与すべき咬合様式に ついて，ガイドライン委員会によって集積されたデー

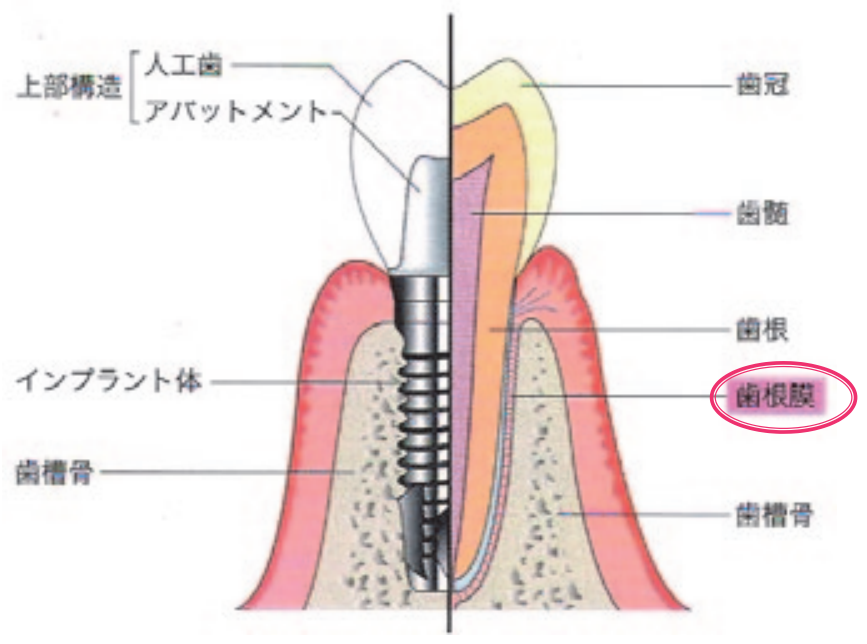

図 1 Structure of a dental implant and a natural tooth インプラントと天然歯の構造

タとインプラント関連エキスパートパネルの経験から 得られた意見をもとに考察を加えたので, ここにポジ ションペーパーとして報告する.

\section{II.インプラント支持固定性補綴装置の特徵}

1. インプラントと天然歯との相違点（図 1)

まず，第 1 にインプラント自体には歯根膜組織が ないことが挙げられる。加えて，天然歯にみられるよ うな歯根膜による緩衝作用も欠如しているため, 以下 の現象が想定できる.

-天然歯にみられる咬合力の増加に伴う咬合接触の 変化がインプラントではみられない.

・わずかな早期接触を回避できない。

- 天然歯歯根膜では存在する圧感覚受容器がないた め，鋭敏な感覚が欠如している.

上記理由から，インプラント補綴を行う際には，装 着時の咬合調整，そしてその後の咬合状態の管理を天 然歯以上に注意を払いながら行う必要がある。

\section{2. 歯根膜による咬合力緩衝作用を考慮した咬合様式} 前述のように，インプラントとそれに結合する骨組 織との間には, 歯根膜組織が介在しない。 その観点 から提唱されているインプラントの咬合論としては, Misch の Implant-protected occlusion が広く知られ ている。人歯冠の咬頭傾斜を緩くし，咬合面を縮小 するなどして，インプラント体に加わる過剩な負荷を 極力排除することを目的とした理論である。 ライト フォースでの噛みしめ時にはインプラント部の咬合を 歯根膜の変位可能な分 $(25 \mu \mathrm{m}$ 程度 $)$ 低くすることで, 


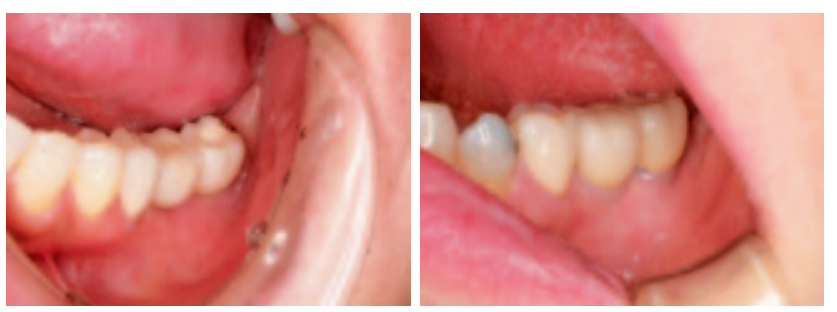

図 2 Intra oral views after the implant prosthesis was placed, that has similar appearance to natural teeth インプラント補綴装置装着後の口腔内写真 : 天然歯同様 の歯冠形態

インプラント周囲の骨に生じる応力を緩和させること が可能と考えられている ${ }^{12-14)}$.

本咬合接触様式は，インプラントと補綴装置にかか る過度のストレスを軽減することを目的とするもので ある。したがって，この状態を維持することが，イン プラント体に装着される補綴装置の破折およびスク リューの緩みや破折，さらにはインプラント体の破折 などを回避するために有効であることは，常識的にも 明らかと思われる。しかしながら，現在までのところ， この概念による咬合付与の臨床的有効性を示すエビデ ンスは示されていない.

\section{3. インプラント体の形状と歯根の形態の相違}

インプラントのレギュラープラットフォームの直径 は約 $4 \mathrm{~mm}$ ，ワイドプラットフォームで約 $5 \mathrm{~mm}$ で ある。それに対して大臼歯部における歯根の近遠心 幅径，煩舌径は，ともにこれより大きい(5)（図 2,3). したがって，インプラント体に，天然歯冠と同様の形 態と大きさを付与した補綴装置を装着すれば，歯冠部 のオーバーハングが大きくなり，それを介してインプ ラント体には，相対的に過度な側方力が加わる可能性 がある。この点についても，常識的には，歯冠部を狭 小化し，過度の側方力がインプラント体に加わらない よう配慮すべきと考えられる.また, 頸部の状態がオー バーカントゥアとなることで，プラークコントロール が困難となり，インプラント周囲炎等，二次的に別の 問題が生じる可能性もある。しかしながら，歯冠部を やや小さく設計する方法論についても，臨床的な有効 性は示されておらず，否定的な報告もある．煩舌的幅 径および咬頭傾斜角の減少に伴い咀嚼運動閉口路は前 方かつ咀嚼側方向へと変化し, 有限要素解析では最大 応力值はほとんど減少せず，応力の垂直成分は減少す るが煩舌側成分は逆に増加することが報告されてい る ${ }^{16)}$. 以前は, 上部構造の咬合面を小さく, 咬頭傾斜 を緩く製作することで，荷重負担を軽減できると考え

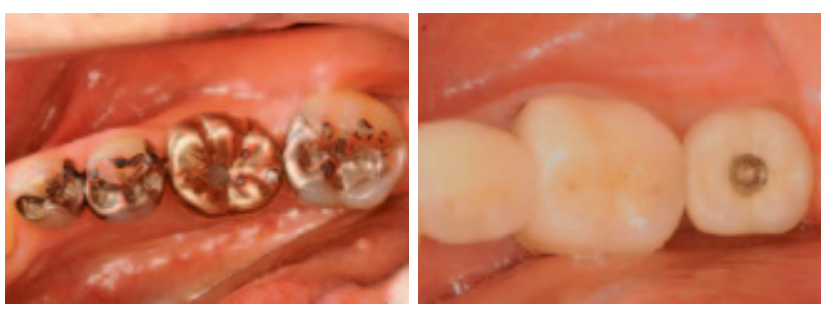

図 3 Intra oral views after the implant prosthesis was placed, that mesiodistal crown diameter was shortened

口腔内写真 (下顎咬合面観) : 近遠心幅径を小さくした歯 冠形態

られており，それが上部構造に好ましい形態であると いった見解が多く見受けられた。しかしながら，極端 に小さく平坦化したような咬合面形態は，咀嚼能率を 低下させ，噛みにくくさせているとも考えられる。つ まり，過度の咬合面の縮小は，インプラント体に側方 力を生じさせる場合もありうることが報告されている ため, 煩舌的幅径および咬頭傾斜角の減少は, 必ずし も有効とは言い難いということになるかもしれない.

\section{4. 下顎大臼歯部欠損にインプラント支持補綴装置 を装着した場合}

下顎の大臼歯部欠損に対して，インプラント支持固 定式補綴装置による治療介入時に, 咬合様式はどのよ うに付与すべきか. もっとも，症例数が多く単純と思 わ机る本症例をとっても，考慮すべき項目は多々あり 慎重に検討すべきである。前述したように，過去の報 告等を考慮したうえで付与すべき咬合は，まず，(1)歯 冠形態やその大きさは天然歯とほぼ同様とし，(2)咬合 接触点の数を十分確保することである。そして，(3)歯 根膜の変位量を考慮した咬合接触にするか，この点は 無視して天然歯同様の咬合調整を行うかは，今後も慎 重な議論が必要と思われる。残存歯がすべて健全であ る状態に限定すれば，補綴装置の破損などを避けるこ とを目的として歯根膜変位量を考慮した咬合調整をし たほうが無難と考えられる。一方，隣接歯あるいは反 対側大自歯群が失活歯の場合，これらの歯に持続的に 過度の咬合負荷がかかれば，歯根破折のリスクを高め る可能性もある。このような場合にはインプラントも 天然歯と同様の咬合支持を担当し，残存歯の保存に貢 献すべきとも考えられる，さらには，対合歯が生活歯 か失活歯かという点まで考慮する必要が出てくる。こ れらの臨床的条件に応じて，咬合付与を多様に設定す ることが必要であるのか，それとも天然歯と同様と考 えて特別な配慮は必要ないのか，この点については， いまだに議論の余地が残されている。 


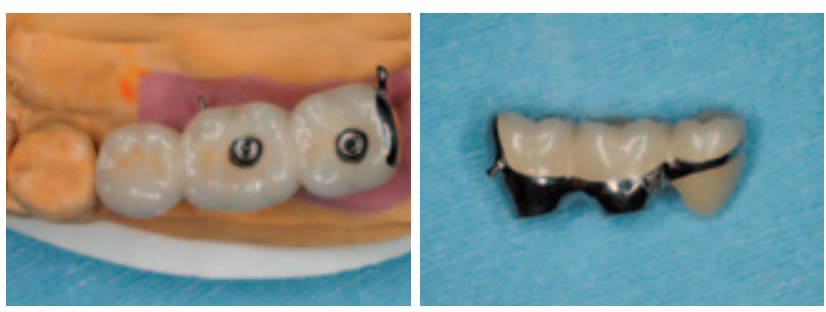

図 4-1 Screw retained restoration of porcelain fused to metal

陶材焼付け金属冠（スクリュー固定）
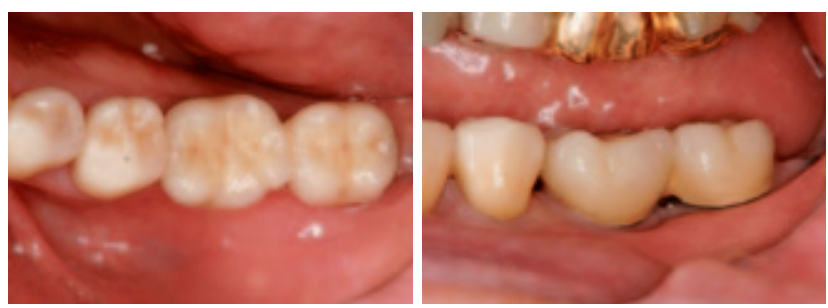

図 4-2 Intraoral views of cement retained restoration of porcelain fused to metal

口腔内写真（下顎咬合面観・側方面観）：陶材焼付け前 装冠（セメント固定）
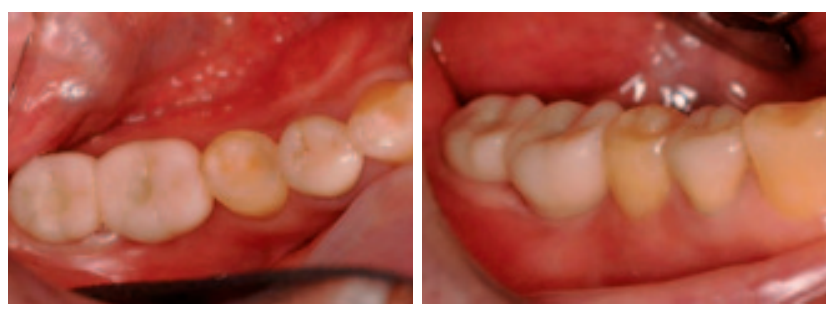

図 5 Intraoral views of screw retained restoration of hybrid composite resin faced metal crowns

口腔内写真 (下顎咬合面観) : ハイブリッド型コンポジッ トレジン前装冠

別の観点からインプラントの上部構造としての補綴 装置の破損について議論を進めると, 用いる材料に関 する検討も必要となる。過去の多くの症例では，審美 的な要件を考慮して陶材焼付冠が多く用いられていた が（図 4)，ハイブリッド型コンポジットレジンの開 発と物性の改善によりハイブリッド型コンポジット レジン前装冠も用いられるようになってきた（図 5). それぞれの短所として，前者には破折した際の修理が 困難であるという問題が，後者には陶材焼付冠と比較 して耐摩耗性に劣り，プラークが付着しやすいなどの 問題が指摘されている。金属材料を用いれば，破折を 憂慮する必要はなくなるが審美的には大きなマイナス となることは否めない（図 6,7)。また，過度な咬合 力が負荷された場合には, 直接インプラント体に応力 が加わることになり，インプラント体の強度次第で

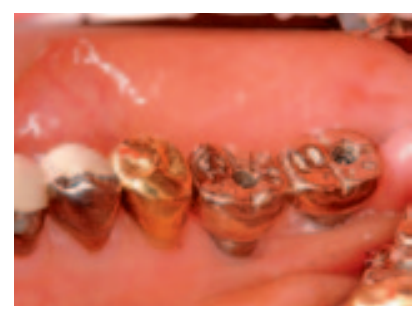

図 6 Intraoral views of screw retained restoration of full metal crowns

口腔内写真 (咬合面観)：フルメタルクラウン
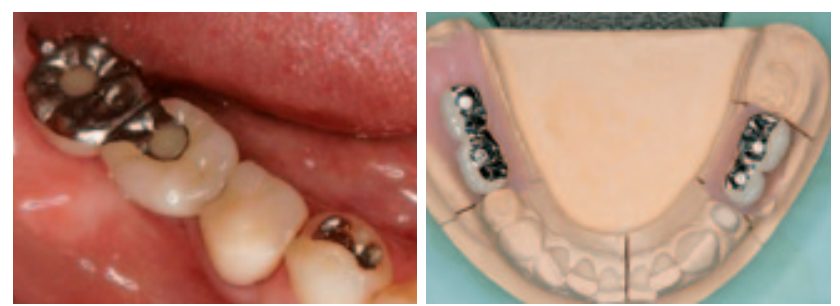

図 7 Screw retained restoration of full metal crowns or porcelain fused to metal made of titanium チタン製フルメタルクラウンとセラミック前装クラウン
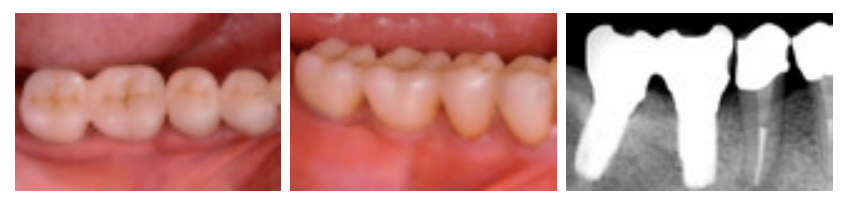

図 8 All ceramic crowns (porcelain fused to zirconia) オールセラミッククラウン（ジルコニアフレーム + ポー セレン築盛)
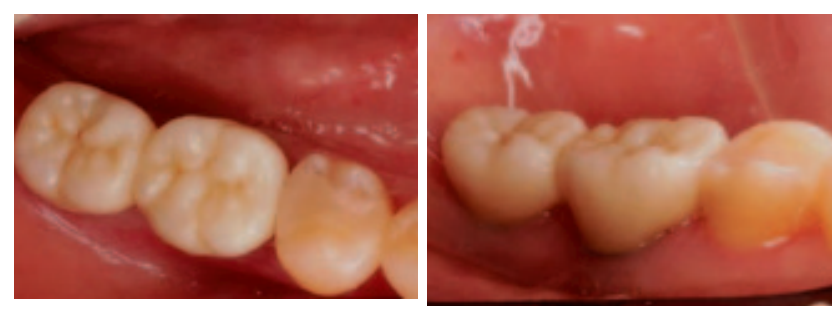

図 9 Intraoral views of full-contoured zirconia crowns 口腔内写真 (下顎咬合面観) : オールジルコニアクラウン

は，インプラント体自体の破折，オッセオインテグ レーションの破綻につながる可能性もある。金属アレ ルギーの観点からも，第一選択とはなり難いと考え る。近年は, 強度の面で大きな改善のみられるジルコ ニアなどの新しいセラミック材料に注目が集まってお り，オールジルコニアクラウンの応用も実用段階にあ る(図 8,9 ).

補綴装置に用いることのできる材料は多種多様であ るが，単純に材料の選択のみが予後を決定するわけで はなく, 咬合様式と併せて検討することが重要と考え 
られる。次項では, 上記検討課題に対してインプラン ト治療のエキスパートが，臨床の現場でどのように対 応しているかを調査した結果を示す。

\section{III. 付与すべき咬合様式についての エキスパート・オピニオン}

前述の疑問点を明らかにするため，「下顎の大臼歯 部欠損に対して，インプラント支持固定式補綴装置に よる治療介入時に付与する咬合様式」について，エキ スパートパネルに対して以下の項目についてアンケー トを行い，エキスパート・オピニオンを要約した。

調査対象とした症例は，以下の要件を満たすもので ある。

1. 下顎 片側 大臼歯部 遊離端 欠損 (下顎の 片側 第一大臼歯と第二大臼歯欠損）

2. 残存歯は天然歯とする。

3. 残存歯に病的な疾患は認めないものとする.

4. 欠損部の顎骨は理想的な骨量，骨質であるものと する．すなわち，下顎の第一大臼歯と第二大臼歯 の遊離端欠損にレギュラープラットフォームのイ ンプラントを 2 本埋入している平易な症例を想定. 骨幅の狭いもの，骨移植症例などは，今回は除外す る。

5. ブラキシズムなどの悪習癖はないものとする。

本ポジションペーパーは, 臨床的に高頻度な状況に 対する臨床的な指針を示すことを目標とし，下顎第一 大臼歯と第二大臼歯の 2 歯欠損に対するものとした ため，必ずしもすべての症例に対応可能なものではな い. また, 欠損形態が異なる他の症例では, 補綴装置 の設計にも当然他の要素を考慮したうえで本ペーパー に示されている指針を変更する必要が生じてくる。

以下 $\mathrm{A}, \mathrm{B}, \mathrm{C}, \mathrm{D}$ の症例にあげられるように, 下顎 第一大臼歯と第二大臼歯の 2 歯欠損だけを例にとつ ても，臨床的条件は多様であるため，主にAまたは それに準ずる症例を調査の対象とすることとした。

A. レギュラープラットフォーム（直径 $4 \mathrm{~mm}$ 前後) のインプラントならば 2 本確実に埋入できるが, ワイドプラットフォームを埋入するには，骨幅がや や不足しているケース，日本人の患者の場合，この タイプが非常に多いと思われる。

-天然歯の歯根の近遠心径および㚘舌径に比較して インプラントの幅径は小さくなる.

・補経装置の歯冠形態を天然歯同様にすれば，オー バーハングが大きくなり, 補綴装置の破折やインプ ラントに対する過度の側方力の原因となる可能性
がある。

・オーバーカントゥアであることから, 清掃困難とい う問題も生じる.

・術者によっては，これらを回避するため，歯冠を天 然歯よりもやや小さく設計する場合がある.

B. ワイドプラットフォーム（直径 $5 \mathrm{~mm}$ 前後かそ れ以上）のインプラントが 2 本確実に埋入できる 骨量が十分なケース。

・天然歯とほぼ同様な歯冠形態を付与することが容 易である。

- 煩舌的な骨幅の余裕は少なくなるため, インプラン トの埋入ポジションは, 制限される. 理想的な位置 に確実に埋入する自信がない場合，（術者の技量に よっては）レギュラープラットフォームのインプラ ント 2 本の埋入を選択することもある.

C. ワイドプラットフォーム（直径 $5 \mathrm{~mm}$ 前後かそ れ以上）のインプラントが下顎第二大臼歯相当部に は埋入できる（第一大臼歯にはレギュラープラット フォームしか入らない) ケース.

・上記，A，B と同様の状況が予想される.

D. 補経主導型治療で骨造成（骨幅拡大）して，ワイ ドプラットフォーム（直径 $5 \mathrm{~mm}$ 前後かそれ以上) のインプラントが理想的な位置に 2 本埋入できる ケース。この術式が採用される頻度は比較的少ない と思われる。

・シミュレーションを行い，ガイデッドサージェリー を応用すれば, 天然歯とほぼ同様な歯冠形態を付与 することが容易である。

上記に示した $\mathrm{A} \sim \mathrm{D}$ に分類できるものだけでなく， CTによる骨量と形態の把握および埋入シミュレー ションの結果，隣接歯根の傾斜，抜歯窩の残存，下顎 管の走行などの影響で, 補経装置の設計は左右される こともある。

また, 患者の経済的事情や対合歯とのクリアランス, さらにはリスク回避の手段として総合的に判断した結 果，短縮歯列として第一大臼歯までの補綴という選択 肢もありうるが, 今回はそのようなケースは除外した。

\section{調査結果のまとめ}

1. 歯冠形態

顎堤の状態に応じて, 天然歯同様とする場合とや や小さくする場合がある.

2. 咬合面形態

顎堤の状態に応じて, 天然歯同様とする場合とや や小さくする場合がある. 
3. 咬合接触点の位置と数

B は必須, $\mathrm{A}$ と C は症例によっては接触させない.

4. 第一大臼歯の接触点の数

$3-5$ 点

5. 側方運動時の咬合接触の有無 なし。

6. 歯根膜の変位量の考慮

・考慮する必要はない。

- 対合歯が生活歯の場合は考慮する必要はない が，失活歯の場合は考慮すべきである.

- 歯根膜変位量（最大でも $25 \mu \mathrm{m}$ 程度）を考慮 する。

7. 第一大臼歯と第二大臼歯の咬合接触は異なるか 必ずしも同様ではない.

8. 補綴装置の種類

陶材燒付冠，ハイブリッド型コンポジットレジン 前装冠，全部金属冠

9. 補綴装置の咬合面の材料は

ポーセレン，ハイブリッド型コンポジットレジ ン，金属材料

\section{IV．結論と今後の展望}

上記調査結果より，下記の咬合様式の付与を推奨す

る。

・咬合面形態と歯冠の幅径等は，天然歯に準じたもの とする，場合によっては，㚘頁径を縮小した形態と する。

・隣接歯，対合歯を含む残存歯が健全かつ対合歯が生 活歯である場合には，天然歯同様の咬合調整を行 う。

-それに対して，隣在歯，対合歯を含む残存歯が健全 かつ対合歯が失活歯である場合には，歯根膜の変位 量を考慮した咬合調整を行う。すなわち残存歯に対 して最大 $25 \mu \mathrm{m}$ ほど低位となるよう調整を行う。

・咬合接触点に関しては，インプラントの長軸に荷重 が伝達されるよう B コンタクトを付与することが 望ましく，さらに咬合の安定を図るため，偏心位で の干渉を避けた上で A，C コンタクトを付与し，1 歯あたり 3 点の接触点を目標とする。またインプ ラント長軸から接触点が大きく逸脱するような場 合はインプラントへの側方力が危惧されることか らその付与を避ける。

・側方運動時には接触しない臼歯離開咬合とする.

・補綴装置としては，陶材焼付冠，ハイブリッド型コ ンポジットレジン前装冠が推奨される。レジンまた はセラミックの破折等が懸念される場合には，咬合
面に金属材料を用いる。または全部金属冠とする場 合もある。

・セラミック材料の進歩により, ジルコニアフレーム や咬合面にジルコニアを用いたフルジルコニアク ラウンなどの使用も試されており，今後の調査報告 が待たれる。

最後に，本ポジションペーパーの内容は，前向き臨 床研究によるエビデンスを包括しておらず，過去の文 献とエキスパート・オピニオンに基づくひとつの見解 である。また，下顎大臼歯欠損というきわめて限られ た条件に対するものでもあり，個々の症例に対応する 際のひとつの基準と考えていただきたい.

中でも，咬合調整の際に歯根膜の変位量を考慮する かどうかについては，明確な統一見解を示すことがで きなかった。「インプラントと天然歯は連結すべきで はない」という原則を挙げるまでもなく，歯根膜を有 する天然歯とインプラントを同様なものとみなすのは 誤りと考えられ，天然歯が咬合したときどう変位する のかを考慮するのは必然である。咬合力が発揮された 機能状態で天然歯と調和するように咬合調整が行われ れば理想的である。すなわち，ライトタッピング時に おける早期咬合接触点を正確に削り，側方運動時の干 渉を除去する作業を繰り返し行った末に，咬合力を発 揮した状態においても天然歯と調和した咬合接触状態 に至るという咬合調整の過程を経て，患者固有の咬合 を構築すべきである。しかし，どの程度の噛みしめ強 度を基準に調整するのかが必ずしも明確にされておら ず，実践すること自体が容易ではない。さらにはこの ような咬合調整が，非常に難しいという技術的な側面 から，インプラントの咬合調整はとくに天然歯の調整 と区別して行う必要はないという意見が少なくないの かもしれない.

実際の臨床の現場で，天然歯と同様の咬合調整を 行った場合においても，対合歯が健全な生活歯であれ ば，起きうる問題はセラミックの破折が主なもので, 重篤な問題が生じているわけではない。一方，わずか な歯根膜の変位量を考慮して咬合調整を行うことの意 義は，インプラント補綴装置およびインプラント自体 の長期予後獲得だけでなく，対合歯に過度の咬合負荷 をかけて咬合性外傷または歯根破折等を惹起すること を避けることにある。この場合には，わずかかもしれ ないが咬合接触状態が変化する可能性があるので，メ インテナンスの際に，必要に応じて咬合調整をすべき である。したがって，いずれの咬合調整法も，論理的 に否定できるものではなく，いずれを採用しても結果 
として臨床的には大きな問題を生じていない.今後は, 順次対応症例の数を増やして，咬合調整に関しても明 確な方法を示し，ガイドラインの策定につなげていく 予定である。

結論として，インプラント支持固定式補綴装置に与 えるべき咬合様式は，天然歯に近い歯冠形態に，B コ ンタクトを基本に咬合接触を付与し，臼歯離開咬合と なるように調整することを基本にすべきであると考え る。そして，歯根膜の変位を考慮しながら咬合調整を 行った結果，隣接する天然歯に近い咬合接触状態また は天然歯と同様の咬合接触状態が得られれば臨床的に は問題ない.

\section{文献}

1) Bragger U, Karoussis J, Persson R, Pjetursson BE, Salvi G, Lang NP. Technical and biological complications/ failures with single crowns and fixed partial dentures on implants: a. 10-year prospective cohort study. Clin Oral Implants Res 2005; 16: 326-334.

2) Romeo E, Lops D, Margutti E, Ghisolfi M, Chiapasco M, Vogel G. Implant supported fixed cantilever prostheses in partially edentulous arches. A seven year prospective study. Clin Oral Implants Res 2003; 14: 303-311.

3) Berglundh T, Persson L, Klinge B. A systematic review of the incidence of biological and technical complications in implant dentistry reported in prospective longitudinal studies of at least 5 years. J Clin Periodontol 2002; 29(Suppl 3): 197-212.

4) Sethi A, Kaus T, Sochor P, Axmann-Krcmar D, Chanavaz M. Evolution of the concept of angulated abutments in implant dentistry: 14-year clinical data. Implant Dent 2002; 11: 41-51.

5）松下恭之, 佐々木健一, 郡 英寛, 江崎大輔, 春田明日香, 古谷野 潔，インプラント咬合にエビデンスはあるか? 補綴誌 $2008 ; 52: 1-9$.

6）土井直洋, 井上美香, 稲井哲司, 渡辺 誠, 佐々木啓一. 臼歯部遊離端欠損インプラント補綴症例の歯列上咬合力.
日口腔インプラント誌 $2006 ； 19 ： 466-477$.

7) Misch CE. Occlusal considerations for implantsupported prostheses: Implant protective occlusion and occlusal materials. In: Misch CE, Bidez MW (eds). Contemporary implant dentistry, 2nd ed. St. Louis: Mosby 1999: 609-628.

8) Schulte W. Implants and the periodontium. Int Dent J 1995; 45: 16-26.

9) Yuan JC, Sukotjo C. Occlusion for implant-supported fixed dental prostheses in partially edentulous patients: a literature review and current concepts. J Periodontal Implant Sci 2013; 43: 51-57.

10) Naert I, Duyck J, Vandamme K. Occlusal overload and bone/implant loss. Clin Oral Implants Res 2012; 23(Suppl. 6): 95-107.

11) Carlsson GE. Dental occlusion: modern concepts and their application in implant prosthodontics. Odontology 2009; 97: 8-17.

12) Kim Y, Oh TJ, Misch CE, Wang HL. Occlusal considerations in implant therapy: clinical guidelines with biomechanical rationale. Clin Oral Implants Res 2005; 16: 26-35.

13) Misch CE, Bides MW. Implant-protected occlusion. Int J Dent Symp 1994; 2: 32-37.

14) Misch CE, Bidez MW. Implant-protected occlusion : A biomechanical rationale. Compendium 1994; 15: 1330-1343.

15）戸室政之, 渡邊文彦, 高瀬一郎, 畑 好昭. インプラント 径選択のための日本人歯頸部径の計測. 日ロ腔インプラン 卜誌 $2010 ; 23(1): 12-17$.

16）中野 環. 機能下におけるインプラント補綴の咬合に関す る力学的研究. 阪大歯学誌 $1996 ; 41: 56-78$.

\footnotetext{
著者連絡先 : 近藤 尚知

T 020-8505 岩手県盛岡市内丸 19-1 岩手 医科大学歯学部補綴・インプラント学講座

Tel: 019-651-5111

Fax: 019-652-3820

E-mail: hkondo@iwate-med.ac.jp
} 


\title{
"Occlusal consideration for fixed implant prosthesis in mandibular posterior region"
}

\author{
Hisatomo Kondo, DDS, PhD ${ }^{\mathrm{a}, 1}$, Shogo Ozawa, DDS, PhD ${ }^{\mathrm{b}, 1}$, Takashi Sawase, DDS, PhD ${ }^{\mathrm{c}, 2}$, \\ Atsuro Yokoyama, DDS, $\mathrm{PhD}^{\mathrm{d}, 2}$, Hideshi Sekine, DDS, $\mathrm{PhD}^{\mathrm{e}, 2}$, Takeo Maida, DDS, $\mathrm{PhD}^{\mathrm{f}, 2}$, \\ Yasunori Ayukawa, DDS, $\mathrm{PhD}^{\mathrm{g}, 2}$, Tamaki Nakano, DDS, $\mathrm{PhD}^{\mathrm{h}, 2}$, Takayasu Kubo, DDS, $\mathrm{PhD}^{\mathrm{i}, 2}$, \\ Ryuji Hosokawa, DDS, $\mathrm{PhD}^{\mathrm{j}, 2}$, Yoritoki Tomotake, DDS, $\mathrm{PhD}^{\mathrm{k}, 2}$, Hirofumi Kido, DDS, $\mathrm{PhD}^{1,2}$, \\ Morio Ochi, DDS, $\mathrm{PhD}^{\mathrm{m}, 2}$, Makoto Shiota, DDS, $\mathrm{PhD}^{\mathrm{n}, 2}$, Masahiko Ozeki, DDS, $\mathrm{PhD}^{\mathrm{o}, 2}$, \\ Masahiro Nishimura, DDS, $\mathrm{PhD}^{\mathrm{p}, 2}$, Yoshinobu Maeda, DDS, $\mathrm{PhD}^{\mathrm{q}, 2}$, Hideki Aita, DDS, $\mathrm{PhD}^{\mathrm{r}, 1}$, \\ Katsushi Tamaki, DDS, PhD ${ }^{\mathrm{s}, 1}$, Kenji Fueki, DDS, PhD ${ }^{\mathrm{t}, 1}$, Hiroaki Tsukasaki, DDS, PhD ${ }^{\mathrm{u}, 1}$, \\ Takahiro Ono, DDS, $\mathrm{PhD}^{\mathrm{q}, 1}$, Yasuyuki Matsushita, DDS, $\mathrm{PhD}^{\mathrm{v}, 2}$, Yoshizo Matsuka, DDS, PhD ${ }^{\mathrm{w}, 1}$, \\ Hajime Minakuchi, DDS, $\mathrm{PhD}^{\mathrm{x}, 1}$, Rika Kuwatsuru, DDS, $\mathrm{PhD}^{\mathrm{g}, 1}$, Shuichiro Yamashita, DDS, $\mathrm{PhD}^{\mathrm{y}, 1}$, \\ Tomoaki, Iizuka, DDS, PhD", ${ }^{z, 1}$ Kazuyoshi Baba, DDS, PhD", , Masanori Fujisawa, DDS, $\mathrm{PhD}^{\mathrm{z}, 1}$, \\ Kiyoshi Koyano, DDS, $\mathrm{PhD}^{\mathrm{g}, 1}$ and Hirofumi Yatani, DDS, $\mathrm{PhD}^{\mathrm{h}, 1}$
}

\begin{abstract}
${ }^{a}$ Prosthodontics and Oral Implantology, School of Dentistry, Iwate Medical University, ${ }^{b}$ Department of Removable Prosthodontics, School of Dentistry, Aichi Gakuin University, 'Department of Applied Prosthodontics, Graduate School of Biomedical Sciences, Nagasaki University, ${ }^{d}$ Department of Oral Functional Prosthodontics, Division of Oral Functional Science, Graduate School of Dental Medicine, Hokkaido University, ${ }^{\mathrm{e}}$ Division of Oral Implantology, Department of Prosthodontics, School of Dentistry, Ohu University, ${ }^{\mathrm{f}}$ Division of Advanced Prosthodontics, Department of Oral Rehabilitation, School of Dentistry, Health Sciences University of Hokkaido, ${ }^{\mathrm{g}}$ Section of Implant and Rehabilitative Dentistry, Division of Oral Rehabilitation, Faculty of Dental Science, Kyushu University, ${ }^{\mathrm{h}}$ Department of Fixed Prosthodontics, Osaka University Graduate School of Dentistry, ${ }^{i}$ Clinic of oral implants, Department of preventive and restorative dentistry, Hiroshima University Hospital, ${ }^{j}$ Division of Oral Reconstruction and Rehabilitation, Faculty of Dentistry, Kyushu Dental University, ${ }^{\mathrm{k}}$ Oral Implant Center, Tokushima University Hospital, ${ }^{~}$ Section of Oral Implantology, Department of Oral Rehabilitation, Fukuoka Dental College, ${ }^{\mathrm{m}}$ Division of Fixed Prosthodontics and Oral Implantology,

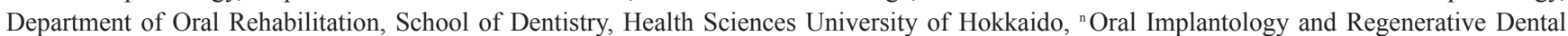
Medicine, Graduate School of Tokyo Medical and Dental University, ${ }^{\circ}$ Department of Oral Implantology, Showa University School of Dentistry, ${ }^{\mathrm{p}}$ Department of Oral and Maxillofacial Prosthodontics, Graduate School of Medical and Dental Sciences, Kagoshima University, ${ }^{\mathrm{q}}$ Division of Comprehensive Prosthodontics, Niigata University Graduate School of Medical and Dental Sciences, ${ }^{\mathrm{r} D i v i s i o n}$ of Occlusion \& Removable Prosthodontics, Health Sciences University of Hokkaido, ${ }^{\mathrm{s}}$ Department of Prosthodontic Dentistry for Function of TMJ and Occlusion, Kanagawa Dental University, ${ }^{t}$ Removable Partial Prosthodontics, Oral Health Sciences, Graduate School of Medical and Dental Sciences, Tokyo Medical and

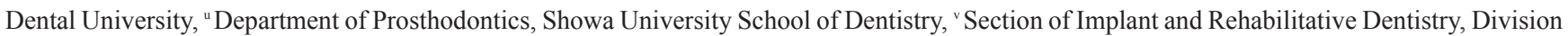
of Oral Rehabilitation, Faculty of Dental Science, Kyushu University, wDepartment of Stomatognathic Function and Occlusal Reconstruction, Institute of Biomedical Sciences, Tokushima University Graduate School, ${ }^{\times}$Department of Oral Rehabilitation and Regenerative Medicine, Okayama University Graduate School of Medicine, Dentistry and Pharmaceutical Sciences, ${ }^{y}$ Department of Removable Partial Prosthodontics, Tokyo Dental College, ${ }^{2}$ Division of Fixed Prosthodontics, Meikai University School of Dentistry, ${ }^{1}$ Japan Prosthodontic Society, Clinical Guideline Committee, ${ }^{2}$ Japan Prosthodontic Society, Implant Expert panel
\end{abstract}

Ann Jpn Prosthodont Soc 8: 1-9, 2016

\begin{abstract}
Clinical guidelines or definitive criteria for "Occlusal consideration for fixed implant prosthesis in mandibular posterior region" have not been established yet although the dental implant is an essential treatment option for current prosthetic dentistry. This position paper aimed to propose a critical recommendation and consequently indicate a tentative practice guideline. In this paper, the first and second molar missing in the mandible was assumed as the most typical partial edentulous jaw. A panel of clinical experts concerning dental implant practice was selected from the members of the Japan Prosthodontic Society, and a meeting was held to collect clinical data obtained from daily practice and to estimate expert opinions. As a result, general remarks were presented regarding shapes of prostheses, position and number of occlusal contact points, occlusal contact during lateral excursion, displacement of periodontal ligament, and materials of occlusal surface. However, the expert opinions described above have not been supported by clinical evidence. Moreover, neither the effect of those therapies nor long-term prognosis has been thoroughly investigated. Thus, further study for collecting the clinical evidences is required to formulate the clinical guideline.
\end{abstract}

Key words: Implants, Fixed prosthesis, Occlusion, Shape of crown, Periodontal ligament 